benefit from iloprost. Administered to four patients suffering from multiple cholesterol emboli, iloprost caused the disappearance of most cyanotic lesions, with a dramatic relief of pain, and, in at least one patient, stabilised and subsequently improved renal function. These cases suggest that the drug should be initiated early to stabilise, and even reverse, the clinical syndrome, but only randomised controlled trials can provide firm evidence of a beneficial effect of iloprost in this syndrome.

In cholesterol emboli syndrome cholesterol crystals obstruct small arterioles, causing local ischaemia and end organ damage. Iloprost, a prostacyclin stable analogue used for treating critical leg ischaemia, Raynaud's syndrome, and pulmonary hypertension, ${ }^{3}$ is a potent vasodilator and antiplatelet aggregant, which stabilises endothelial integrity and has cytoprotective properties. This might explain our clinical observations in these four patients.

Contributors: All authors initiated the project and searched, extracted, analysed, and participated in discussing the results and writing the paper. TCS is the guarantor.

Funding: None.

Competing interest: None declared.

1 Kara HVK, Yunis JP, Mason RA, Giron F. After the blue toe: prognosis of noncardiac arterial embolization in the lower extremities. I Vasc Surg 1993;17:328-35.

2 O'Keefe ST, Woods B, Breslin DJ, Tsapatsaris NP. Blue toe syndrome. Arch Intern Med 1992;152:2197-202.

3 Grant SM, Goa KL. Iloprost. Drugs 1992;43:889-924.

\title{
Challenges in managing profound hypokalaemia
}

\begin{abstract}
Abnormalities of serum potassium are associated with well described clinical features: lassitude when potassium $<3.5 \mathrm{mmol} / \mathrm{l}$, possible muscle necrosis at $<2.5 \mathrm{mmol} / \mathrm{l}$, and a flaccid paralysis with respiratory compromise at $<2 \mathrm{mmol} / \mathrm{l}$. World wide, hypokalaemia is most often caused by diarrhoea, although specific treatment of hypokalaemia is not mentioned in international guidelines for managing gastroenteritis. ${ }^{2}$ Furthermore, a recent case made us concerned that the potassium replacement recommended in medical texts (a maximum rate of infusion of $0.3-0.5 \mathrm{mmol} / \mathrm{kg} /$ hour and a maximum daily replacement of $3-5 \mathrm{mmol} / \mathrm{kg}$ ) may be inadequate for profound hypokalaemia $(\leqslant 1.5$ $\mathrm{mmol} / \mathrm{l})$.
\end{abstract}

\section{Patients, methods, and results}

The patient (case 1, table) was an 8 month old child with gastroenteritis who was too weak to respond appropriately to pain, with reduced respiratory effort, metabolic acidosis, intermittent sinoatrial block, and an inappropriately low heart rate (72 beats/min) given the degree of dehydration. The risk of inadequate treatment seemed to outweigh the risk of aggressive fluid and potassium replacement as mechanical ventilation and inotropic support were not available. The maximum recommended administration rate and total daily dose for intravenous potassium were therefore exceeded by at least 4 and 3 fold respectively without adverse effects.

We identified further cases with potassium concentrations $\leqslant 1.5 \mathrm{mmol} / \mathrm{l}\left(614 \mathrm{Na}^{+} / \mathrm{K}^{+}\right.$Analyser, Chiron Diagnostics) from paediatric admissions to the high dependency unit of Kilifi District Hospital in 1993-2000. Data were extracted from the case records and examined for blood gas and potassium values at 4-8 hours and 18-30 hours after admission (early and late resuscitation phases). The maximum and average hourly rates and total of potassium infusion during resuscitation were calculated.

Thirteen patients, seven of whom died, were identified (table). In four death was too rapid to allow evaluation, and in one survivor data were inadequate. Strikingly, nine out of 11 patients with data on blood gases on admission were markedly acidotic. Although acidosis was persistent (possibly confounding potassium measurements) and continued stool losses could not be measured, there was a significant correlation between the late phase change in potassium and the average rate of potassium replacement over 24 hours (Spearman's $\tau 0.78$, $\mathrm{P}=0.02)$. The only child developing a potassium value $>5.6 \mathrm{mmol} / 1$ during admission was a child with a Gram negative septicaemia (case 8): potassium rose to $6.6 \mathrm{mmol} / \mathrm{l}$ ( $\mathrm{pH} 6.99$, base excess $-23.9 \mathrm{mmol}$ ) at 48 hours, shortly before death.

\section{Comment}

Current guidelines for potassium replacement may not deal adequately with the rare but life threatening situation of profound hypokalaemia ( $\leqslant 1.5 \mathrm{mmol} / \mathrm{l})$ associated with metabolic acidosis seen in our developing country setting. Furthermore, recent prospective data suggest that half the children admitted with gastroenteritis have a base excess $\leqslant-10$ $\mathrm{mmol}$ and $7 \%$ a potassium $<2 \mathrm{mmol} / \mathrm{l}$ (PS, unpublished data) even though acidosis would normally be expected to increase potassium concentrations (due to efflux of intracellular potassium in exchange for extracellular hydrogen). About 500 children with gastroenteritis and 300 with severe malnutrition are admitted to our hospital annually, so the problem of hypokalaemia with acidosis is important.

Globally, lack of resources makes it likely that such hypokalaemia is rarely recognised. Paradoxically, therefore, children with severe gastroenteritis, perhaps at highest risk of hypokalaemia, may receive intravenous fluids ${ }^{2}$ with little or no potassium $(0.9 \%$ saline, Ringer's lactate, or Hartmann's). In fact by ameliorating any associated acidosis through correcting hypovolaemia or direct alkalinisation (by lactate) cells may import potassium in exchange for intracellular hydrogen ions, further lowering serum
Potentially life threatening profound hypokalaemia with metabolic acidosis may not be adequately dealt with by current treatment recommendations

University of Edinburgh Medical School, Edinburgh EH8 9AG William Welfare medical student

Centre for Geographic Medicine Research, Coast, KEMRI/ Wellcome Trust Research Laboratories, $\mathrm{PO}$

Box 230, Kilifi,

Kenya

Phillip Sasi

research fellow

Mike English research paediatrician

Correspondence to: M English menglish@kilifi. mimcom.net

BMJ 2002;324:269-70 
Characteristics of cases identified as profoundly hypokalaemic on admission and response to treatment

\begin{tabular}{|c|c|c|c|c|c|c|c|c|c|c|c|c|}
\hline \multirow[b]{2}{*}{ Case } & \multirow[b]{2}{*}{ Diagnosis } & \multirow[b]{2}{*}{$\begin{array}{c}\text { Age } \\
\text { (mnths) }\end{array}$} & \multicolumn{3}{|c|}{ Admission } & \multicolumn{2}{|c|}{$\begin{array}{l}\text { Serum potassium } \\
\text { change (mmol/l) }\end{array}$} & \multirow[b]{2}{*}{$\begin{array}{c}\text { Base } \\
\text { excess at } \\
\sim 24 \text { hours }\end{array}$} & \multirow{2}{*}{$\begin{array}{l}\text { Maximum rate } \\
\text { potassium } \\
\text { infusion } \\
\text { (mmol/kg/h) }\end{array}$} & \multirow{2}{*}{$\begin{array}{c}\text { Total } \\
\text { potassium } \\
\text { given in } \\
\sim 24 \text { hours } \\
(\mathrm{mmol} / \mathrm{kg})\end{array}$} & \multirow{2}{*}{$\begin{array}{c}\text { Total fluid } \\
\text { administered } \\
\text { in } 24 \text { hours } \\
(\mathrm{ml} / \mathrm{kg})\end{array}$} & \multirow[b]{2}{*}{ Outcome } \\
\hline & & & $\begin{array}{c}\text { Potassium } \\
(\mathrm{mmol} / \mathrm{l})\end{array}$ & $\mathrm{pH}$ & $\begin{array}{c}\text { Base } \\
\text { excess } \\
(\mathrm{mmol})\end{array}$ & Early & Late & & & & & \\
\hline 1 & Gastroenteritis & 8 & 0.7 & 7.09 & -24.5 & 1.1 & 2.7 & -19.2 & 2 & 14.5 & 220 & Alive \\
\hline 2 & Gastroenteritis & 14 & 0.9 & 7.06 & -23.3 & 0.9 & 1.8 & - & 0.4 & 6.1 & 210 & Alive \\
\hline 3 & $\begin{array}{l}\text { Gastroenteritis/ } \\
\text { severe protein } \\
\text { calorie } \\
\text { malnutrition }\end{array}$ & 12 & 1.1 & 7.23 & -20.2 & - & 1.1 & -20.4 & 1.2 & 4.0 & 200 & Alive \\
\hline 4 & $\begin{array}{l}\text { Gastroenteritis/ } \\
\text { severe protein } \\
\text { calorie } \\
\text { malnutrition }\end{array}$ & 25 & 1.2 & - & - & 0.4 & 1.8 & - & 0.5 & 9.0 & 140 & Alive \\
\hline 5 & $\begin{array}{c}\text { Gastroenteritis/ } \\
\text { malaria }\end{array}$ & 6 & 1.5 & 7.25 & -17.6 & - & 1.3 & -6.5 & 0.2 & 2.7 & 180 & Alive \\
\hline 6 & Gastroenteritis & 10 & 1.0 & 7.08 & -13.9 & 0.9 & $3.0^{*}$ & -14.6 & 1.0 & $7.0^{*}$ & $220^{*}$ & Dead $^{*}$ \\
\hline 7 & Gastroenteritis & 8 & 1.1 & 7.06 & -24.6 & 0.7 & 2.5 & -26.2 & 0.5 & 5.0 & 195 & Dead† \\
\hline 8 & $\begin{array}{l}\text { Meningitis/ } \\
\text { septicaemia }\end{array}$ & 4 & 1.5 & 7.12 & -17.5 & - & 2.7 & -21.2 & 1.2 & 7.5 & 150 & Deadf \\
\hline \multicolumn{13}{|c|}{ Children with inadequate data during admission, including early deaths } \\
\hline 9 & $\begin{array}{l}\text { Gastroenteritis/ } \\
\text { severe protein } \\
\text { calorie } \\
\text { malnutrition }\end{array}$ & 11 & 0.8 & - & - & - & - & & - & - & - & Alive \\
\hline 10 & Gastroenteritis & 6 & 0.9 & 6.97 & -24.9 & - & - & & - & - & - & Dead \\
\hline 11 & $\begin{array}{c}\text { Gastroenteritis/ } \\
\text { severe protein } \\
\text { calorie } \\
\text { malnutrition }\end{array}$ & 22 & 1.1 & 7.44 & -6.3 & - & - & & - & - & - & Dead \\
\hline 12 & $\begin{array}{l}\text { Gastroenteritis/ } \\
\text { acute } \\
\text { respiratory } \\
\text { infection }\end{array}$ & 7 & 1.3 & 7.38 & -14.7 & - & - & & - & - & - & Dead \\
\hline 13 & $\begin{array}{l}\text { Gastroenteritis/ } \\
\text { severe protein } \\
\text { calorie } \\
\text { malnutrition }\end{array}$ & 11 & 1.4 & 7.14 & -19.6 & - & - & & - & - & - & Dead \\
\hline
\end{tabular}

${ }^{*}$ Died at 18 hours, had $7 \mathrm{mmol} / \mathrm{kg}$ potassium before death and fluids at a rate equivalent to $200 \mathrm{ml} / \mathrm{kg} / 24 \mathrm{~h}$. †Died at 48 hours, admitted in coma and did not regain consciousness after admission. ‡Died at about 48 hours as described in the text.

potassium with possibly disastrous consequences. ${ }^{3}$ Further research on potassium replacement in severe gastroenteritis is required, particularly in potentially life threatening, profound hypokalaemia.

We gratefully acknowledge the help of the clinical and laboratory staff of Kilifi District Hospital and the KEMRI/ Wellcome Trust Research Laboratories. ME is supported by a Wellcome Trust Career Development Fellowship. This paper is published with the permission of the director of KEMRI

Contributors: ME conceived the study and contributed to data collection, analysis, and drafting the manuscript. WW undertook data collection and analysis and was involved in drafting the manuscript. PS helped in data collection and interpreting and drafting the manuscript.

Funding: ME is supported by a Wellcome Trust career development fellowship.

Competing interests: None declared.

1 Gennari FJ. Hypokalemia. N Engl J Med 1998;339:451-8.

2 World Health Organization. Management of the child with a serious infection or severe malnutrition. Geneva: World Health Organization, 2000.

3 Heyman S, Nehama H, Horovitz J, Sofer S, Orbach J, Amir Y, et al. Sudden death from fluid resuscitation: lesson from Ruanda. Lancet 1994;344:1509-10.

\section{One hundred years ago}

\section{The cigarette and the depopulation problem}

The list of ill effects attributed to tobacco is already longer than Homer's catalogue of the ships. That pleasant poison is held accountable for intermittency of the pulse and palpitation of the heart; for dyspepsia, gastralgia, and loss of appetite; for angina pectoris, various disorders of vision, tendency to vertigo, loss of memory, blunting of sensibility and impairment of motor power Tremor and obstinate cough are also reckoned for unrighteousness to the herb nicotian. The hardened smoker is even said to bear the mark of his vicious habit stamped upon him in the most intimate part of his anatomy, colouring his bones as he does his pipes. But he defies, all the vaticinations of medical oracles, and indeed as he generally feels no wound he can afford to jest at scars. A new Cassandra has, however, recently arisen, in the person of Dr. Le Juge de Segrais, of Luchon, who in the current number of the Archives Générales de Médecine foretells what many smokers will regard as a worse doom than any yet pronounced upon them. He holds that among the baleful effects of tobacco on the nervous system is one which makes it unlikely that the smoker will see children of his own about his knees. Carlyle tells a story of a squire of dames who was wounded in a duel in such a manner that although he lived many years afterwards and broke most of the commandments, one he observed with the strictest fidelity, for the good and sufficient reason that a breach of it was beyond his power. If we are to believe Dr. Le Juge de Segrais, a rigid obedience to the same commandment is sometimes imposed on the devotee of My Lady Nicotine. He cites two cases from published records, and several more from his own practice, in which impotence resulted from inordinate smoking.

(BMJ 1902;i:981) 